\title{
Two new hosts for Caligus bonito Wilson C.B., 1905 (Copepoda, Siphonostomatoida, Caligidae) from Turkey
}

\author{
AHMET ÖKTENER ${ }^{1, \bullet}$, ALI ALAS ${ }^{2}$, DILEK TÜRKER ${ }^{3}$ \\ ${ }^{1}$ Deparment of Fisheries, Sheep Research Station. Çanakkele Street 7km.,10200, Bandırma, Balıkesir, Turkey. Tel.: +90-5072397983, `email: \\ ahmetoktener@yahoo.com \\ ${ }^{2}$ Department of Biology, Faculty of Education, Necmettin Erbakan University. B Block, 42090, Meram, Konya, Turkey \\ ${ }^{3}$ Department of Biology, Faculty of Science, Balikesir University. Cagis Campus, 10300, Balikesir, Turkey
}

Manuscript received: 22 May 2017. Revision accepted: 26 June 2017

\begin{abstract}
A, Alaş A, Türker D. 2017. Two new hosts for Caligus bonito Wilson C.B., 1905 (Copepoda, Siphonostomatoida, Caligidae) from Turkey. Bonorowo Wetlands 7: 1-3. Caligus bonito Wilson C.B., 1905 (Copepoda, Siphonostomatoida, Caligidae) was reported for the first time on the gill filaments of Sarda sarda (Bloch, 1793), Auxis rochei (Risso, 1810) from Turkish marine waters. The morphological characters of this cosmopolitan parasitic copepod are given using photographs. This study presents two new host species and a new geographic distribution of Caligus bonito in Turkey.
\end{abstract}

Keywords: Copepod, Caligus bonito, Sarda, Auxis, Turkey

\section{INTRODUCTION}

Copepods of the family Caligidae (Siphonostomatoida) are commonly known as sea lice among the fish culturists. It is the largest family of marine copepods comprising over 450 species. The members of this family are characteristic in possessing a flattened body, which is well adapted for life on a moving object - the fish. They feed on their host's blood, mucus, and epithelial cells (Ho 2004). This family has been responsible for most documented disease outbreaks (Johnson et al., 2004).

Hitherto, only ten species of the Caligidae family have been recorded parasitizing fishes in Turkish marine habitats. They are Caligus apodus (Brian 1924), Caligus bonito Wilson C.B., 1905, Caligus brevicaudatus Scott, 1901, Caligus lagocephali Pillai, 1961, Caligus minimus Otto, 1821, Caligus pageti Russel, 1925, Caligus pelamydis Krøyer, 1863, Caligus solea Demirkale, Özak, Yanar, Boxshall, 2014, Caligus temnodontis Brian, 1924, and Lepeophtheirus europaensis Zeddam, Berrebi, Renaud, Raibaut, Gabrion, 1988 (Alaş et al. 2016). In this paper, we present a second report of the male of Caligus bonito Wilson C.B., 1905, with morphological characters from Turkey.

\section{MATERIAL AND METHODS}

Thirty-three of Atlantic bonito, Sarda sarda (Bloch, 1793) (Scombridae) and forty-two of bullet tuna, Auxis rochei (Risso, 1810) (Scombridae) were collected by local gears from the Sea of Marmara, the Aegean Sea Coasts of Turkey) in 2014. The collected parasitic copepods were preserved in $70 \%$ ethanol. Some specimens were cleared in lactic acid before dissection of the appendages of copepods. The drawings of appendages were carried with the aid of camera lucida (Olympus BH-DA). The photos were taken with Canon EOS 1100D connected to a microscope. Measurements were taken in millimeters $(\mathrm{mm})$ with a micrometric program (Pro-way). The scientific names and synonyms of parasite and host were checked with WoRMS Editorial Board (2016) and Froese and Pauly (2016). The identification, scientific names, their synonyms of the parasite were checked with Wilson (1905), Brian (1935), Kabata (1979), Cressey and Cressey (1980), Cressey (1991), Ho and Lin (2004). The parasite (MNHNIU-2013-18732) was deposited in the Museum National d'Histoire Naturelle (MNHN), Paris, France.

\section{RESULTS AND DISCUSSION}

\section{Caligus bonito Wilson, 1905 (Copepoda,} Siphonostomatoida, Caligidae)

Host: Sarda sarda, Auxis rochei

Locality: Bandırma Bay, Babakale Port

Total parasite: 5 males; Dissected material: 2 males

All parasites were firmly attached to the gill filaments of the host. The prevalence of parasite was $6 \%$ for Sarda sarda and $7.1 \%$ for Auxis rochei

Malemorphology (Figure 1-2): Body length varies from 4.5 to $5 \mathrm{~mm}$. Maxilliped 3-segmented; proximal segment with ornamentation has four small tubercules, a distal segment comprising claw with a short seta. The setae on the exopod of the first leg carry teeth. The first segment of the second leg endopod carries four teeth, while the second segment with teeth in two slightly alternating rows. Distribution: Caligus bonito was cosmopolitan, found in all waters inhabited by its wide-ranging hosts. It was reported from the Mediterranean Sea, the Black Sea, The Atlantic Ocean, the Pacific Ocean (Kabata 1979). 


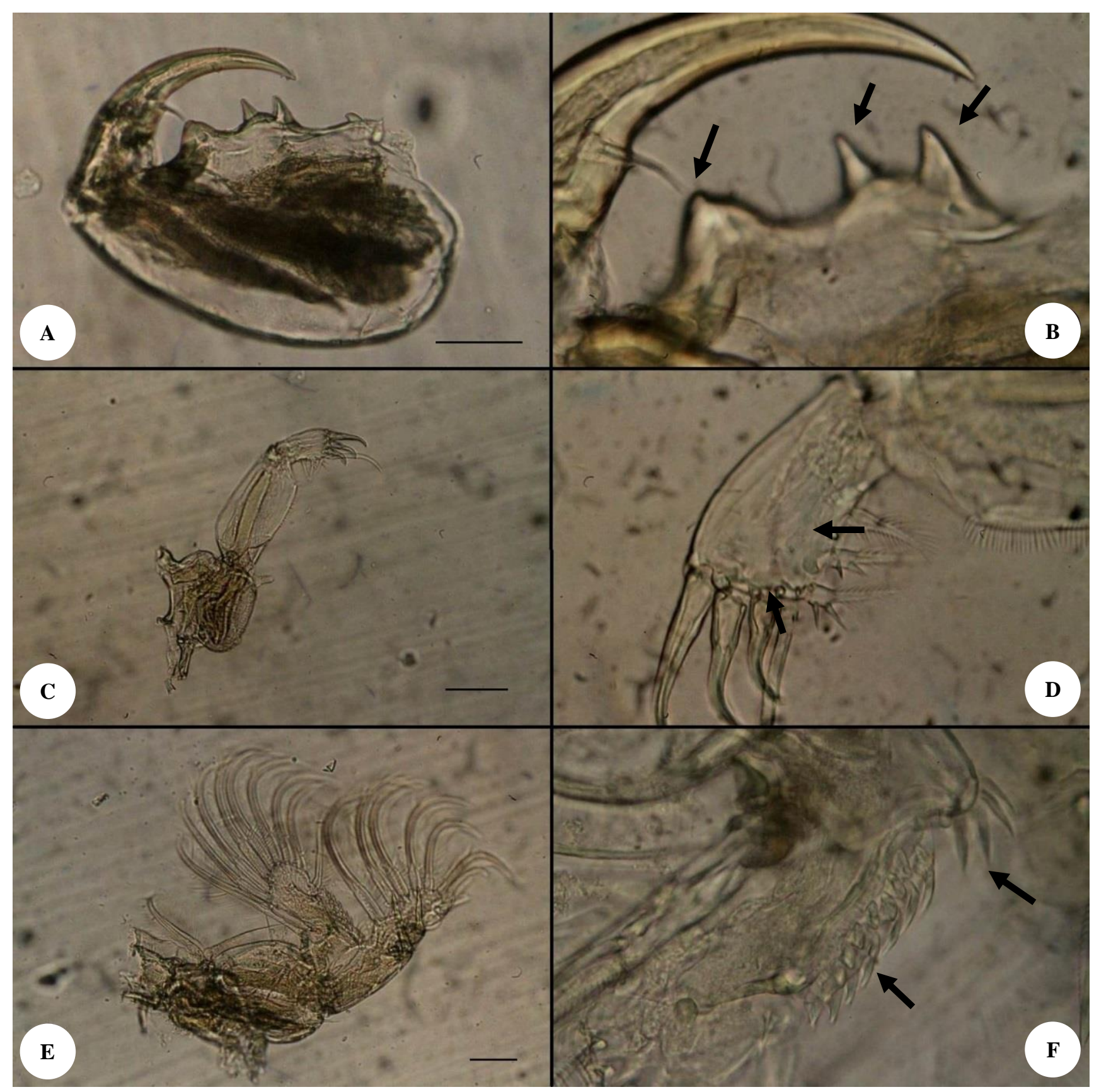

Figure 1. Caligus bonito $\hat{\jmath}$. A. Maxilliped $(\mathrm{Bar}=0.075 \mathrm{~mm})$, B. Four small tubercules on proximal segment of maxilliped, C. First leg $($ Bar $=0.10 \mathrm{~mm})$, D. Setae on exopod of the first leg, E. Second leg $($ Bar $=0.08 \mathrm{~mm})$, F. Four teeth and teeth in two slightly alternating rows on the first and second segment of second leg endopod

Hosts: Caligus bonito parasitizes several teleost species belonging to the family Scombridae, such as Euthynnus affinis, Euthynnus alletteratus, Katsuwonus pelamis, Sarda sarda, Sarda orientalis, Sarda australis, Sarda chilensis chilensis, Scomberomorus regalis, Thunnus thynnus, Euthynnus lineatus, Gymnosardaunicolor (Walter and Boxshall 2008), Scomberomorus carvalla, Scomberomorus maculatus (Bere 1936). However, it has been collected on hosts from other families (Mugilidae, Carangidae,
Lutjanidae, Sciaenidae, Pomatomidae, Serranidae, Coryphaenidae), including Mugil cephalus, Oligoplites saurus, Lutjanus griseus, Pomatomus saltatrix (Bere 1936), Mugil platanus (Knoff et al. 1994), Mugil curema (Cavalcanti et al. 2006), Oligoplites palometa (Takemoto and Luque 2002), Cynoscion nebulosus (Blanchet et al. 2001), Cratinus agassizii, Lutjanus novemfasciatus, Trachurus murphyi (Ho and Lin 2004), and Coryphaena hippurus (Ho and Lin 2004; Öktener and Trilles 2009). 


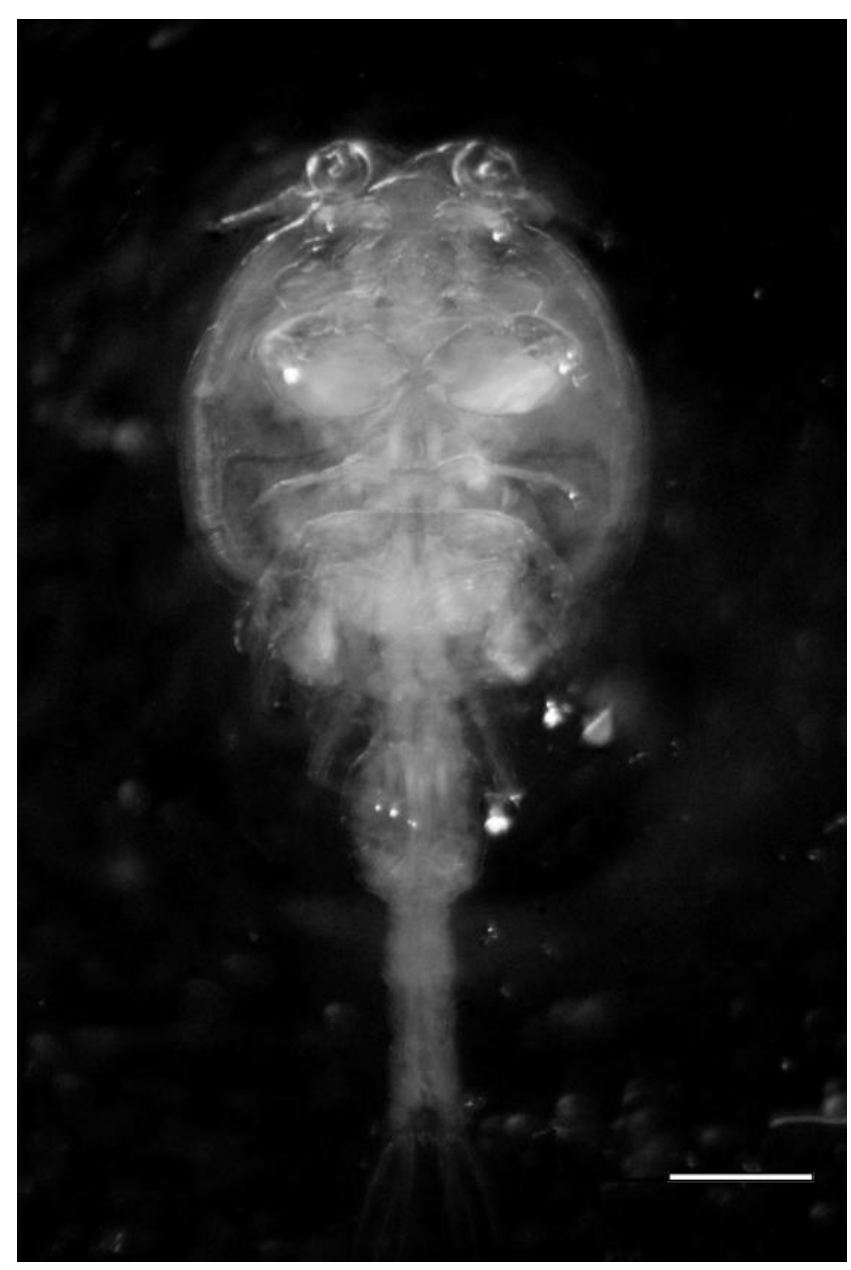

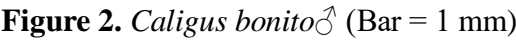

\section{Discussion}

Significantly, the Scombridae family fishes are the host of Caligus bonito. This parasite selects carnivorous and pelagic fishes as hosts for habitat and feeding habits. This study examined Sarda sarda ve Auxis rochei, carnivorous and pelagic fish. It is fit for host preferring of Caligus bonito.

Concerning the studies about the prevalence values of Caligus bonito, Takemoto and Luque (2002) found 3.57\% prevalence on Oligoplites palometa; Knoff et al. (1994) found $13.33 \%$ prevalence on Mugil platanus; Cavalcanti et al. (2011), 3.23\% prevalence on Mugil curema. The low prevalence values on Sarda sarda $(6 \%)$ and Auxis rochei $(7.1 \%)$ show the similarity with Takemoto and Luque (2002), Cavalcanti et al. (2011). Both differences in the infestation values and morphology of the parasite can result from the parasite-host interactions and host species that have migratory character.

The morphological characters found in this study are compared with mainly (Wilson 1905; Brian 1935; Lewis 1967; Pillai 1969; Kabata 1979; Cressey and Cressey 1980; Cressey 1991; Ho and Lin, 2004). The general morphology, three adhesion pads on the antenna, teeth on three setae of exopod of the first leg, four teeth and teeth in two slightly alternating rows on the first and second segment of second leg endopod, maxilliped proximal segment with four small tubercules, the setal and spinal formula of from the first leg to the fourth leg in this study are compatible according to this literature. The morphologic features of all dissected parasites permitted identification of this copepod as Caligus bonito Wilson, 1905. This study was aimed to present two new host species and a new geographic distribution of Caligus bonito in Turkey.

\section{REFERENCES}

Alaş A, Öktener A, Türker Çakır D. 2015. Review of parasitic copepods recorded in fish from Turkey. Transylvanian Rev Syst Ecol Res 17 (1): 39-62. DOI: 10.1515/trser-2015-0047.

Bere R. 1936. Parasitic copepods from Gulf of Mexico fish. Am Midland Naturalist 17 (3): 577-625. DOI: 10.2307/2419936.

Blanchet H, Hoose MV, Mceachron I, Muller B, Warren J, Gill J, Waldrop T, Walker J, Adams C, Ditton R, Shively D, Vanderkooy S. 2001. The Spotted seatrout fishery of the Gulf of Mexico, US: A Regional Management Plan. The Gulf States Marine Fisheries Commission 87.

Brian A. 1935. I Caligus parassiti dei pesci del Mediterraneo (Copepodi). Annali del Museo Civico di Storia Naturale 'Giacomo Doria', Genova 57 (7): 152-211.

Cavalcanti ETS, Chellappa S, Pavenelli GC, Takemoto RM. 2006. Report on the occurrence of Caligus bonitoand Caligus sp. (Copepoda: Caligidae) on the White mullet, Mugil curema (Osteichthyes: Mugilidae), off Natal, Rio Grande do Norte State. Arquivos de Ciências do Marine 39: 131-133.

Cressey R, Cressey HB. 1980. Parasitic Copepods of mackerel- and tunalike fishes (Scombridae) of the world. Smithsonian Contrib Zool 311: 1-186. DOI: $10.5479 /$ si.00810282.311.i.

Cressey R. 1991. Parasitic Copepods from the Gulf of Mexico and Caribbean Sea, III: Caligus. Smithsonian Contrib Zool 497: 1-53. DOI: $10.5479 /$ si.00810282.497.

Froese R, Pauly D. 2016. FishBase. www.fishbase.org.

Ho JS, Lin CL. 2004. Sea lice of Taiwan (Copepoda: Siphonostomatoida: Caligidae). The Sueichan Press, Keelung, Taiwan.

Ho JS. 2004. Invasiveness of sea lice (Copepoda, Caligidae) in marine aquaculture. J Fish Soc Taiwan 31 (2): 85-99.

Johnson SC, Treasurer JW, Bravo S, Nagasawa K, Kabata Z. 2004. A review of the impact of parasitic copepods on marine aquaculture. Zool Stud 43 (2): 229-243.

Kabata Z. 1979. Parasitic Copepoda of British Fishes. Ray Society Publications. The British Museum, London.

Knoff M, Luque JL, Takemoto RM. 1994. Parasitic copepods on Mugil platanus Günther from the Coast of the State of Rio De Janeiro. Braz J Vet Parasitol 3 (1): 45-56.

Öktener A, Trilles JP. 2009. Four parasitic copepods on marine fish (Teleostei and Chondrichthyes) from Turkey. Acta Adriatica 50 (2): 121-128.

Takemoto RM, Luque JL. 2002. Parasitic copepods on Oligoplites spp. (Osteichthyes, Carangidae) from the Brazilian coastal zone, with the redescription of Tuxophorus caligodes Wilson, 1908 (Siphonostomatoida, Tuxophoridae). Acta Scientiarum Maringá 24 (2): 481-487.

Walter TC, Boxshall G. 2008. Caligus bonito Wilson C.B., 1905. In: Walter TC, Boxshall G (eds) World of Copepods database. http://www.marinespecies.org/aphia.php? $\mathrm{p}=$ taxdetails\&id=135745.

Wilson CB. 1905. North American parasitic Copepods belonging to the family Caligidae, 1: The Caliginae. Proc U.S. Nat Mus 28: 479-672. DOI: $10.5962 /$ bhl.title.59333.

WoRMS Editorial Board. 2016. World Register of Marine Species. http://www.marinespecies.org. 